ROCZNIKI TEOLOGICZNE

Tom LXVII, zeszyt $9-2020$

DOI: http://dx.doi.org/10.18290/rt20679-10

DOROTA ŚWITAŁA-TRYBEK

\title{
ŚWIĘTY JACEK W RELIGIJNOŚCI LUDOWEJ I W KULTURZE POLSKIEJ
}

\author{
SAINT JACK IN FOLKLORE RELIGIOSITY \\ AND POLISH CULTURE
}

\begin{abstract}
St. Jacob Odrowąż, a Dominican born in Kamien Śląski close to Opole, canonized in 1594 by Clement VIII, is one of the most prominent figures of the thirteenth century. He is considered to be the founder of the Polish province of the Dominican and initiator of the creation of many monasteries in Poland, Prussia, the Czech Republic (Znojmo, Jihlava, Olomouc and Prague) and Austria (Friesach on the border between Styria and Catharinia). He is called the Apostle of the Northern Europe, the Apostle of the Slavs, the Light of the North, Lux ex Silesiae (the Light from Silesia); he carried out evangelization among the peoples inhabiting today's Baltic countries and the Black Sea grasslands, also in Kievan Rus. This article is an attempt to discuss and analyse the cult of St. Jack in Polish tradition and religious culture. The author presents the biography of the Saint, legends and myths associated with him as well as proverbs, agrarian and culinary customs. The materials used in this article come from field research that the author conducted in the years 2015-2020, as well as from the available literature.
\end{abstract}

Key words: St. Jacob Odrowąż; cult; religiosity; legends; dumplings.

Święty Jacek (Hiacynt, Jacinto, Giacinto, Jácint) obok św. Jana Pawła II jest najbardziej znanym polskim świętym na świecie. Urodzony nieopodal Opola, zaliczany jest do najwybitniejszych postaci XIII wieku. O jego wielkości świadczy chociażby fakt, iż znajduje się on pośród innych 139 znaczących świętych przedstawionych na kolumnadzie Jana Laurentego Berniniego na placu św. Piotra w Watykanie (zob. fot. 1). Nazywany Apostołem Północnej Europy, Apostołem

Dr hab. DOROTA ŚwitAŁA-TRYBEK, prof. UO - Katedra Nauk o Kulturze i Religii Uniwersytetu Opolskiego; adres do korespondencji: pl. Kopernika 11, 45-040 Opole; e-mail: dtrybek@uni.opole.pl; ORCID: https://orcid.org/0000-0001-8525-5800. 
Słowian, Światłem Północy, Lux ex Silesiae (Światłem ze Śląska) ${ }^{1}$ prowadził misje ewangelizacyjne wśród ludów zamieszkujących dzisiejsze państwa bałtyckie oraz stepy nadczarnomorskie, także w niespokojnej trzynastowiecznej Rusi Kijowskiej. Jego kult, kształtujący się przez stulecia, żywy był we wszystkich krajach, w których dominikanie budowali swoje klasztory, szczególnie zaś we Francji, we Włoszech, a współcześnie w Ameryce Południowej, gdzie znajdują się liczne kościoły mu poświęcone, w tym katedra San Jacinto de Yaguachi (Ekwador), do której każdego roku w dniu 16 sierpnia przybywają setki tysięcy pielgrzymów. Wiele też miast na świecie nosi imię św. Jacka (San Jacinto), np. w Meksyku, Kolumbii, Urugwaju, Stanach Zjednoczonych (Kalifornii i Nevadzie). Jego imieniem nazwano także: pasmo górskie, szczyt, rzekę, dolinę, park narodowy, uskok tektoniczny oraz liczne katolickie szkoły i szpitale. W Polsce do najbardziej znanych ośrodków kultu należą Kamień Śląski - miejsce urodzenia późniejszego dominikanina (zob. fot. 2), oraz Kraków, gdzie zmarł, tam też w kościele Świętej Trójcy znajdują się jego relikwie.

Przedmiotem niniejszego artykułu jest próba omówienia i analizy kultu św. Jacka w religijności ludowej i kulturze polskiej. Autorka przedstawia biografię świętego, legendy i podania z nim związane, także przysłowia, zwyczaje agrarne i kulinaria. Materiały, które stały się podstawą omówienia, pochodzą $\mathrm{z}$ badań terenowych w latach 2015-2020 (udział w odpustach parafialnych, rejestracja miejsc kultu św. Jacka), jak i z dostępnej literatury przedmiotu.

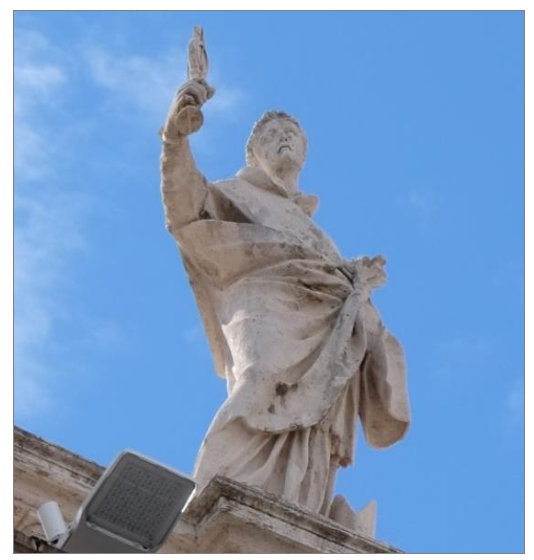

1. Rzeźba św. Jacka na kolumnadzie J.L. Berniniego na placu św. Piotra w Watykanie, fot. D. Świtała-Trybek

\footnotetext{
${ }^{1}$ W 2012 r. w Rzymie odbyło się międzynarodowe sympozjum poświęcone św. Jackowi i jego misyjnej roli w Europie. Zob. Św. Jacek Odrową̇ Apostot Pótnocnej Europy, red. ks. Arkadiusz Nocoń, ks. Arkadiusz Wuwer (Roma-Katowice: Księgarnia św. Jacka, 2012).
} 


\section{WOKÓŁ POSTACI I KULTU ŚW. JACKA}

„Jacek narodu polskiego, dziedzic ze wsi Kamienia, rodzaju był zacnego, z młodości dobrze w bojaźni Bożej wychowany, który mając powinowatego swego Iwona, biskupa krakowskiego, od niego jest kanonikiem krakowskim uczyniony i na kapłaństwo poświęcony" - tak brzmi jeden z początkowych fragmentów Żywota świętego Jacka Polaka zakonu św. Dominika zamieszczony w dziele rektora Kolegium Jezuitów w Wilnie - ks. Piotra Skargi [Skarga, 2011, 168]. Jednakże autorem pierwszego żywota (z połowy XIV wieku) najsłynniejszego polskiego dominikanina był brat Stanisław, lektor szkoły teologicznej w klasztorze pod wezwaniem Świętej Trójcy w Krakowie. Jego dzieło zatytułowane De vita et miraculis Jacchonic ( $O$ żсіu $i$ cudach św. Jacka) powstało w związku ze staraniami o kanonizację, dlatego większość tekstu to opisy cudów, jakie dokonały się za wstawiennictwem św. Jacka [Spież, 2007, 6-7].

Jacek prawdopodobnie urodził się w 1183 r. na Śląsku Opolskim (w Kamieniu Śląskim albo w jego pobliżu, w miejscowości Łąka), pochodził z możnego rodu Odrowążów wywodzącego się z Moraw i osiadłego w okolicach Opola, był krewnym biskupów krakowskich: Iwo Odrowąża i Jana Prandoty oraz błogosławionych: Czesława i Bronisławy. Nauki pobierał w szkole katedralnej krakowskiej, w której później został kanonikiem. Studiował teologię, filozofię i prawo w Paryżu i Bolonii. Około 1221 r., przebywając w Rzymie, wstąpił do nowo powstałego Zakonu Kaznodziejskiego (Ordo Fratrum Praedicatorum), a jego obłóczyn w kościele św. Sabiny dokonał sam założyciel wspomnianego zakonu - św. Dominik Guzman z Kastylii. Po powrocie do Polski, w 1222 r., biskup Iwo przekazał nowo wyświęconym dominikanom (Jackowi, Czesławowi Polakowi i Hermanowi Niemcowi) stary kościół Trójcy Świętej w Krakowie, przy którym (po remoncie) wybudowano klasztor, Jacek został pierwszym jego przełożonym [Kanior, 1987, 98]. Jest on uważany za twórcę polskiej prowincji dominikanów oraz za inicjatora powstania wielu klasztorów w Polsce, Prusach, Czechach (Znojnie, Igławie, Ołomuńcu, Pradze) i Austrii (we Friesach na pograniczu Styrii i Karyntii) [Kanior, 1987, 96]. Jako porywający kaznodzieja i gorliwy kapłan prowadził podróże misyjne na Ruś (12281232), do Prusów (1236-1236 i 1236-1243) i na pobrzeża Litwy [Woroniecki, 2007, 85-54], które były ważnym elementem reformującego się Kościoła w XIII stuleciu, porównywane do tych prowadzonych prawie trzy wieki wcześniej przez św. Wojciecha. Według kwestionowanych źródeł dominikanin dotarł również do Skandynawii (Danii, Szwecji, Norwegii) 
[Wileniec-Sønderby, 2012, 120], także na Krym, a nawet do Indii ${ }^{2}$. Zasięg jego apostolstwa rozciągał się zatem od Adriatyku po Bałtyk, od Odry po Dniestr, dlatego nazywany jest apostołem Słowian i to zarówno przez pracę misyjną, jak również przez zapoczątkowanie na tych terenach przyszłych prowincji dominikańskich [Woroniecki, 2007, 288]. Warto wspomnieć, iż w XIII wieku w polskiej prowincji dominikanów założono 33 klasztory, w tym m.in. w takich miastach jak: Kraków, Wrocław, Kamień, Płock, Sandomierz, Gdańsk, Sieradz, Elbląg, Racibórz, Poznań, Głogów, Lublin, Cieszyn, Legnica, Toruń, Opole, Oświęcim [Kanior, 1987, 288].

Jacek zmarł po dłuższej chorobie w Krakowie 15 sierpnia 1257 r. w uroczystość Wniebowzięcia Najświętszej Maryi Panny. W dniu jego śmierci miały miejsca nadzwyczajne zdarzenia. Norbertanka Bronisława miała widzenie Matki Bożej prowadzącej zakonnika do królestwa chwały, podobną wizję miał biskup krakowski Jan Prandota. Tego samego dnia wydarzył się również cud. Niejaki Żegota spadł z konia i nieszczęśliwie zmarł na miejscu. Zrozpaczeni rodzice zanieśli syna na grób zakonnika, błagając go o ratunek. Po godzinie młodzieniec wstał, mówiąc, że był z Jackiem w raju [Kanior, 1987, 114].

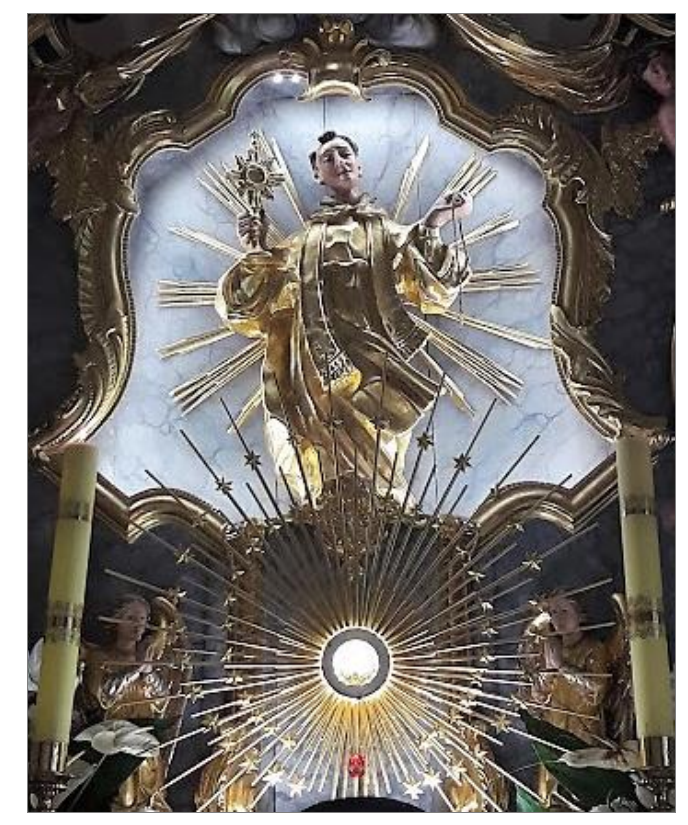

2. Ołtarz w kaplicy św. Jacka w sanktuarium ku jego czci w Kamieniu Śląskim, fot. D. Świtała-Trybek

\footnotetext{
${ }^{2}$ Zob. dostęp: 1.02.2020, https://silesia.edu.pl/index.php?title=\%C5\%9Aw._Jacek.
} 
Papież św. Pius X dzień jego dorocznej pamiątki wyznaczył na 17 sierpnia [Zalewski, 1989, 479]. Dominikanin już za życia cieszył się sławą wielkiego cudotwórcy, dlatego zaraz po jego odejściu podjęto starania kanonizacyjne. Upłynęły prawie trzy wieki zanim został beatyfikowany, co nastąpiło w 1527 r., papież Klemensa VIII w 1594 r. zaliczył go w poczet świętych. Święty Jacek jest historycznym patronem Polski i Litwy, także Krakowa, Kijowa, Wrocławia, jak również Wołynia. Dekretem z 10 lutego 1993 r. św. Jan Paweł II mianował go głównym patronem metropolii katowickiej; jest również opiekunem archidiecezji krakowskiej, diecezji opolskiej oraz patronem kobiet brzemiennych [Cammilleri, 2002, 183] i zagrożonych ciąż (w Gidlach - w sanktuarium Matki Boskiej Gidelskiej małżonkowie oczekujący potomstwa powierzali świętemu zagrożone ciąże. Po latach w dniu odpustu ocalone dzieci zakładały habity dominikańskie) $)^{3}$, także matek udręczonych cierpieniami dzieci, jak i plonów oraz urodzaju.

\section{IKONOGRAFICZNE PRZEDSTAWIENIA ŚW. JACKA}

W ikonografii św. Jacek przedstawiany jest jako mężczyzna w średnim wieku, zawsze $\mathrm{w}$ białym habicie dominikańskim, na którym ma założoną czarną kapę z kapturem w tym samym kolorze, głowę okala tonsura (wygolony krążek obejmujący ciemię lub całą głowę). Jego postawa ciała wyraża głęboką pobożność (złożone ręce, pozycja klęcząca). Do charakterystycznych atrybutów świętego należą: monstrancja (także kielich, kustodia lub cyborium), figurka Matki Bożej, księga i lilia (zob. fot. 3, 4, 5). Pierwsze dwa bezpośrednio nawiązują do legendy o ucieczce dominikanina z Kijowa przed Tatarami, ukazują również dwa fundamenty potrydenckiej teologii katolickiej: kult eucharystyczny i maryjny.

Spośród wielu schematów ikonograficznych (funkcjonujących w malarstwie od XVI wieku) przedstawiających św. Jacka wyróżniają się następujące: objawienie się Matki Bożej dominikaninowi będącemu w stanie modlitewnej ekstazy, która wypowiada zwykle do niego słowa zapisane w łacinie na dekoracyjnej wstędze (Gaude, fili Hiacinte, guia orationes tuae gratae sunt Filio meo et quiduid ab eo per mepetieris impetrabis: „Raduj się, synu Jacku, ponieważ twoje modlitwy miłe są memu Synowi, o cokolwiek Go więc,

\footnotetext{
${ }^{3}$ Dostęp: 1.02 .2020 , http://www.miesiecznik.wdrodze.pl/index_special.php?mod=archiwumtekst \&id=15950\#.XkCWKTFKjIU.
} 


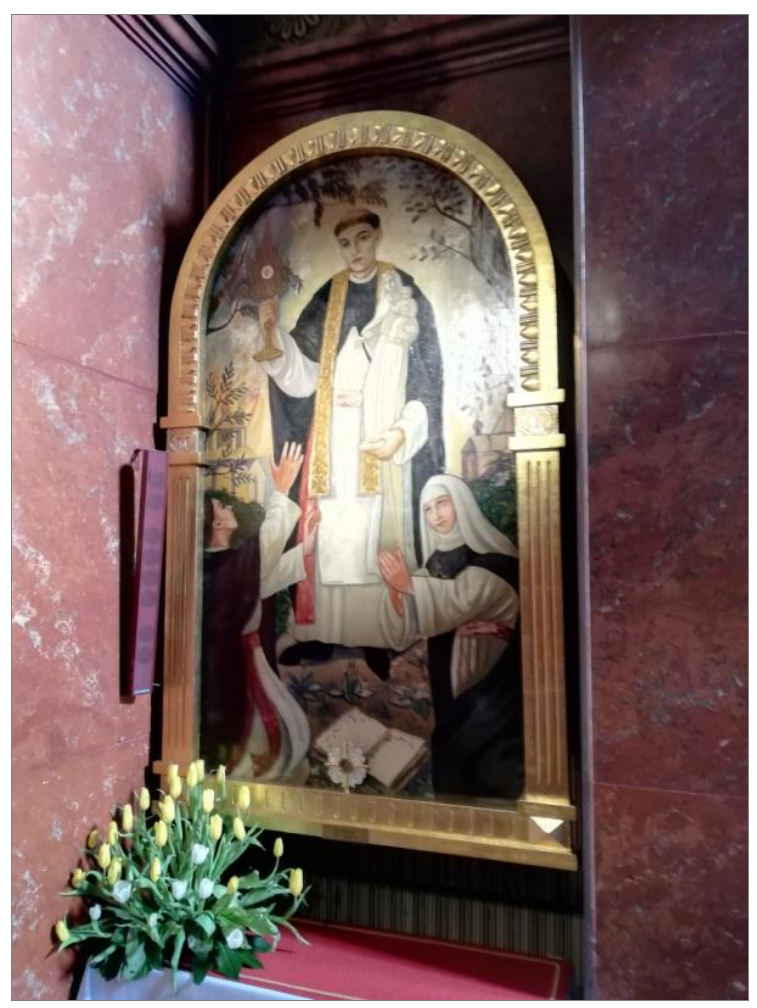

3. Obraz z wizerunkiem św. Jacka, bł. Bronisławy i bł. Czesława w sanktuarium Matki Boskiej Piekarskiej,

Piekary Śląskie, fot. D. Świtała-Trybek

za moim wstawiennictwem, poprosisz - otrzymasz") $)^{4}$; ukazanie świętego w gronie innych mężów wyniesionych na ołtarze, np. św. Rocha, św. Sebastiana, św. Franciszka, św. Dominika, św. Antoniego z Padwy - prawie zawsze w obecności Matki Bożej; także wskrzeszenie przez niego utopionego dziecka; ucieczka przed Tatarami z Kijowa, przekraczanie rzeki Dniepr czy wreszcie obłóczyny i kanonizacja św. Jacka [Fusco, 2012, 65].

Do najbardziej znanych polskich malarskich przedstawień świętego należy obraz zatytułowany Wizja św. Jacka Odroważa, który znajduje się w kościele parafialnym w Odrowążu (pierwotnie wisiał w kaplicy św. Jacka w krakowskim kościele Dominikanów), autorstwa anonimowego artysty krakow skiego

\footnotetext{
${ }^{4}$ Matka Boża miała ukazać się św. Jackowi w wigilię Wniebowzięcia NMP w 1223 r. podczas modlitwy w kościele krakowskim. O tym widzeniu miał mówić swoim współbraciom podczas wędrówki do Gdańska w 1225 r. Marian KANIOR OSB, „Święty Jacek”, w Polscy święci 8, red. Joachim Roman Bar OFMConv (Warszawa: Akademia Teologii Katolickiej, 1987), 84-122.
} 
działającego na przełomie XV i XVI wieku zwanego Mistrzem Zwiastowania z Jodłownika. Obraz przedstawia klęczącego wśród przebogatej roślinności św. Jacka z aureolą wokół głowy wpatrującego się w Matkę Bożą z Dzieciątkiem, która zwraca się do niego słowami zapisanymi po łacinie na wijącej się banderoli. Po prawej stronie w tle widać charakterystyczne budynki Krakowa, a mianowicie kościół Dominikanów z klasztorem i nieistniejący już młyn. W głębi zauważalne są dwa miasta ze świątyniami wznoszącymi się na stromych zboczach, kompozycję dopełnia egzotyczne drzewo rosnące za plecami Jacka [Walczak, 2013, 595-623].

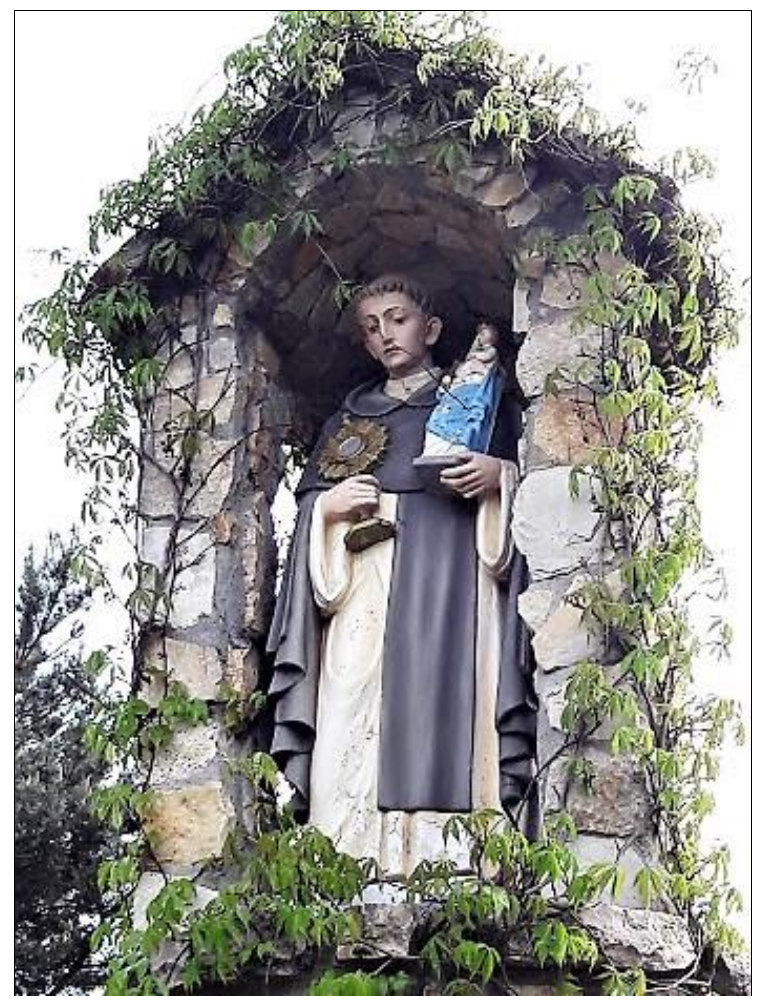

4. Kapliczka św. Jacka w Izbicku, fot. D. Świtała-Trybek 


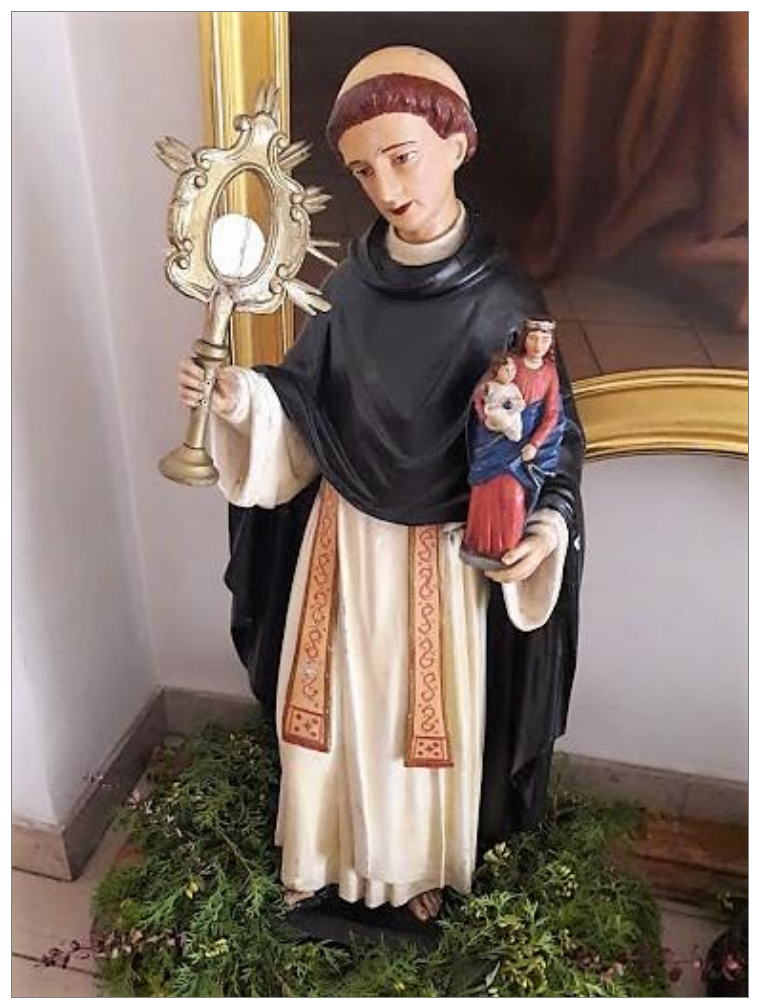

5. Feretron św. Jacka w kościele parafialnym w Kamieniu Śląskim, fot. D. Świtała-Trybek

Święty Jacek był wielkim czcicielem Maryi. Ku jego czci odprawiane są modlitwy i nabożeństwa (np. triduum, nowenna, litania) [Borkowski, 2019] ${ }^{5}$, śpiewane pieśni ${ }^{6}$, a na uroczystości odpustowe do Kamienia Śląskiego i Krakowa przybywają rzesze pielgrzymów. W 1595 r., w pierwszą rocznicę kanonizacji polskiego dominikanina powstał hymn A san Jacinto, którego twórcą był Miguel de Cervantes Saavedra, autor Don Kichota ${ }^{7}$. W 1866 r. na pamiątkę rocznicy wyniesienia na ołtarze św. Jacka ukazał się poemat Kornela Ujejskiego pt. Kanonizacja św. Jacka. Warto również wspomnieć, iż od

${ }^{5}$ Zob. np. Zbigniew BoRkowski, Święty Jacek (Częstochowa: Edycja Świętego Pawła, 2019).

${ }^{6}$ W 1938 r. w Opolu ukazała się niewielkich rozmiarów książeczka z 8 pieśniami i litanią do św. Jacka, pomieszczono w niej również pieśń i litanię do błogosławionej Bronisławy oraz pieśń o błogosławionym Czesławie. Zob. Ku czi św. Jacka (Opole: Wydał Związek Polskich Kół Śpiewaczych na Śląsku Opolskim, (Oppeln O.-S.), 1938).

${ }^{7}$ Hymn A san Jacinto składa się z 8 zwrotek, polskiego przekładu dokonała Bożena Anna Wileniec-Sønderby. Zob. BORKOWSKI, Święty Jacek, 44-46. 
1994 r. nagrodą Lux ex Silesia wyróżnia się osoby, które w swojej działalności naukowej lub artystycznej prezentują wysokie wartości moralne i wnoszą trwały wkład w kulturę Górnego Śląska. Nazwa nagrody nawiązuje do postaci św. Jacka i błogosławionego Czesława.

\section{NIEZWYKŁE WYDARZENIA ZWIĄZANE Z POSTACIĄ ŚW. JACKA}

Święty Jacek już za życia cieszył się sławą jako ten, który dokonuje cudów. Jak już wspomniano, opisy Jackowych interwencji zostały opisane przez lektora Stanisława. Pierwsze boskie zdarzenie z jego udziałem miało miejsce 27 września $1221 \mathrm{r}$. w dniu przeniesienia zwłok św. Stanisława na Skałkę. Jacek w trakcie podróży na tę uroczystość wskrzesił chłopca imieniem Piotr (pochodzącego z Proszowic), który spadł z konia i utonął w Wiśle, a jego ciało dopiero następnego dnia zostało odnalezione. Matka topielca przypadłszy do stóp Jacka prosiła go o pocieszenie. Chłopiec po żarliwej modlitwie dominikanina wstał i zdrów wrócił z rodzicielką do domu. Drugi cud miał miejsce w rodzie Odrowążów, Jacek przywrócił mowę córce wojewody Mikołaja Prandoty, trzecim zaś było uzdrowienie umierającej niewiasty [Woroniecki, 2007, 72].

Do niecodziennego epizodu zapisanego w żywocie lektora Stanisława należy przejście św. Jacka i jego współbraci: Benedykta, Floriana i Godyna, przez wezbraną Wisłę pod Wyszogrodem. Święty rozpostarł wówczas na wodzie swoją kapę, dzięki której „suchą stopą” przeprawili się bezpiecznie na drugi brzeg rzeki. Z kolei z pobytem św. Jacka w Kijowie związana jest opowieść o uzdrowieniu niewidomej córki księcia Włodzimierza Rurykowicza, który w dowód wdzięczności ofiarował dominikanom miejsce na klasztor i kościół [Spież, 2007, 74, 76]. Inna legenda nawiązuje do napadu w 1240 r. Tatarów na Kijów i ucieczki św. Jacka przed Mongołami. Zabierając wówczas z kościoła Najświętszy Sakrament, miał usłyszeć prośbę Matki Bożej, aby wziął także figurę $\mathrm{z}$ jej podobizną, co - pełen obaw ze względu na ciężar rzeźby - uczynił (stała się lekka jak piórko). Podobnie, jak podczas przeprawy przez Wisłę, przeszedł również przez Dniepr bez zmoczenia nóg (zob. fot. 6$)^{8}$.

\footnotetext{
${ }^{8}$ Jacek Woroniecki uważa, że legendzie tej brak podstaw zarówno historycznych, jak i topograficznych. Dominikanów w tym czasie nie było już w Kijowie (Jacek prawdopodobnie przebywał wówczas na misjach w Prusach), nadto miasto leży na prawym (zachodnim) brzegu Dniepru. Nie jest również możliwe, aby w kościele kijowskim znajdowała się statua Matki Boskiej, ponieważ na Wschodzie nie uznawano rzeźby w świątyniach, a sam Zakon Kaznodziejski dwukrotnie zakazywał takich przedstawień na kapitułach generalnych w 1239 i 1240 r. Do dzisiaj, zgodnie z tradycją,
} 
Znane są trzy przedstawienia Matki Boskiej Jackowej, nawiązujące do wyżej przywołanej legendy: w Krakowie, Przemyślu i Lwowie (zob. fot. 7). Święty Jacek pomagał także nieszczęśliwym i zatroskanym ludziom, jak np. bezpłodnej kobiecie, której wymodlił dar macierzyństwa.

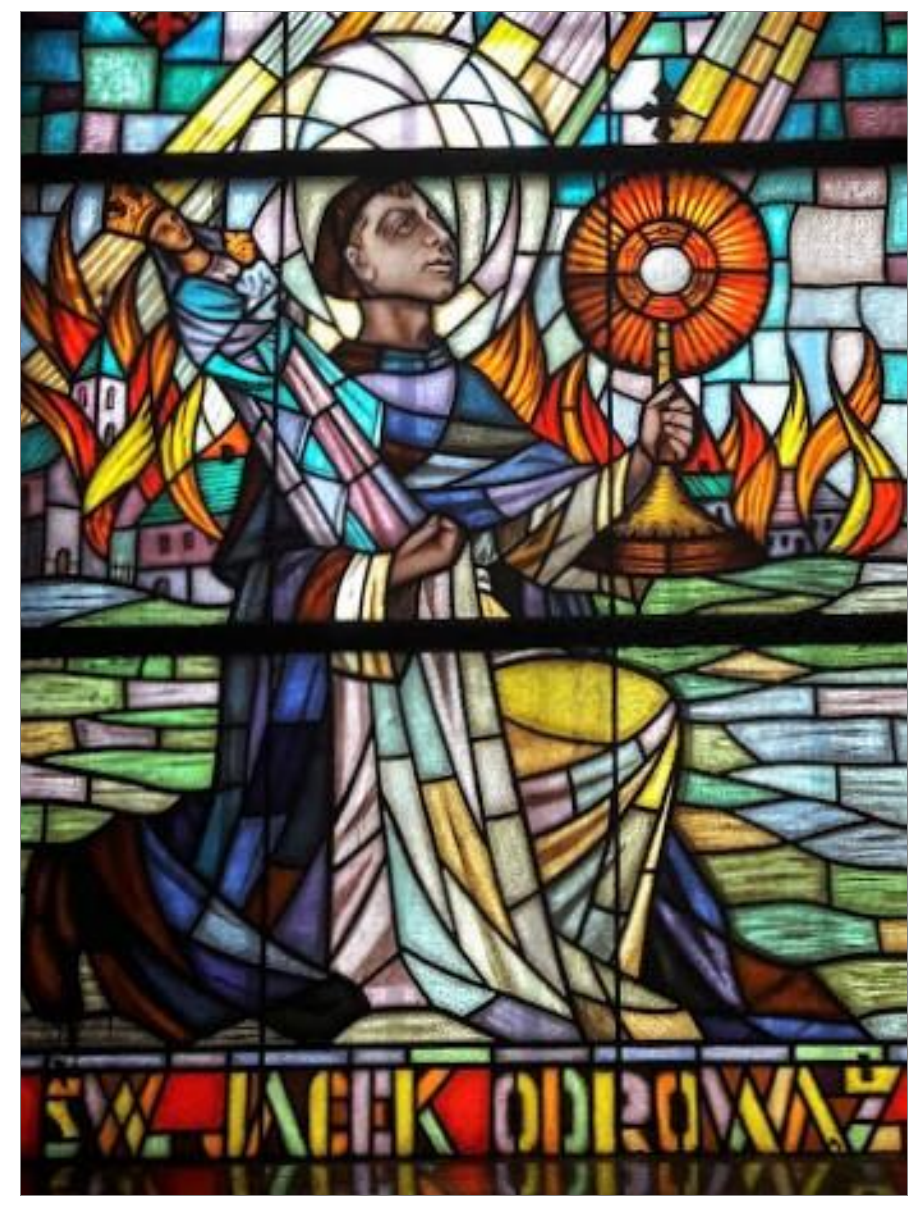

6. Witraż ze św. Jackiem w sanktuarium św. Anny, Góra św. Anny, fot. D. Świtała-Trybek

znane są trzy takie posążki (w Krakowie, Przemyślu i Lwowie), które pretendują do tego, że Jacek wyniósł je z płonącego Kijowa, jednakże wszystkie one mają cechy rzeźby renesansowej. Jacek WORONIECKI OP, Święty Jacek Odroważ i sprowadzenie Zakonu Kaznodziejskiego do Polski (Kraków-Katowice: Esprit, 2007), 94-95. Innego zdania jest Jan Andrzej Spież, który uważa, że Jacek mógł przedostać się na wschodni brzeg Dniepru, a figura, którą wyniósł dominikanin, nie musiała być wielką figurą ołtarzową. Jan Andrzej SPIEŻ OP, Święty Jacek Odrowąż (Kraków: WAM, 2007), 80-81. 


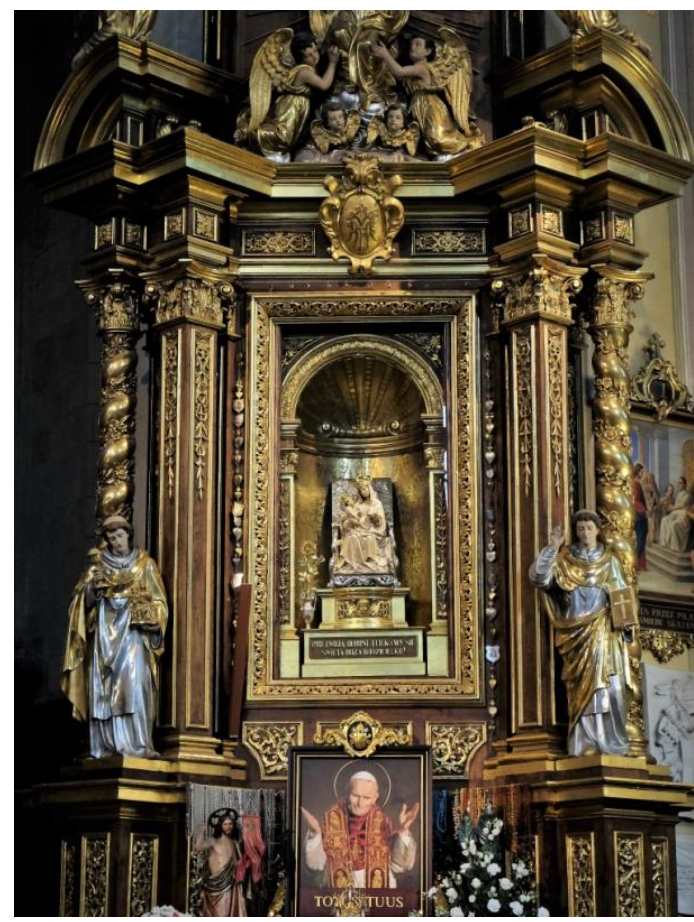

7. Ołtarz z rzeźbą Matki Boskiej Jackowej w bazylice archikatedralnej w Przemyślu, fot. D. Świtała-Trybek

W tradycji ludowej zachowały się również podania o pobycie św. Jacka w Bytomiu, a dokładnie $\mathrm{w}$ jednej $\mathrm{z}$ dzielnic tego miasta - w Rozbarku. Zgodnie z przekazami, dominikanin mieszkał tu przez jakiś czas w swojej pustelni. Pewnego razu podczas głoszenia przez niego kazania zleciała się spora liczba srok, które przeraźliwie skrzeczały. Wówczas Jacek kazał zamilknąć uciążliwym ptakom i wynieść się im w inne miejsce. Sroki osiadły na wzniesieniu, które od tej pory nazwano Sroczą Górą [Jacek z Wygiełzowa, 1922, 5-6]. Motyw srok przeszkadzających i odpędzonych przez świętego łączy się również z tragicznym wydarzeniem w 1367 r., a mianowicie z utopieniem dwóch kapłanów przez bytomian, po którym na miasto został nałożony interdykt [Drabina, 1984, 107-120]. Gdy św. Jacek w czasie homilii potępiał sprawców niegodziwego czynu, przyleciała gromada hałaśliwych srok, które - skarcone przez niego - odleciały i odtąd nie pojawiły się w tych stronach [Lompa, 1965, 176]. W innej rozbarskiej opowieści Jackowi podczas modlitwy przerwał się różaniec nad źródełkiem. Jego paciorki rozleciały się po piasku i zmieszały się z nim tak, że trudno było je wyzbierać. Wtedy 
przyszły święty miał rzec, że mają tak długo rosnąć, dopóki zdrój będzie płynął. Kamienie te, zbierane przez miejscową ludność, nazwano perłami św. Jacka i traktowano jak relikwie [Szczech, 2000, 86-87].

Kolejna opowieść dotyczy pomocy św. Jacka, jaką otrzymali mieszkańcy Oświęcimia podczas oblężenia miasta przez husytów w 1428 r. Obawiając się wroga, który mordował, palił i niszczył wszystko, co spotkał na swej drodze, schronili się w kościele Dominikanów i żarliwie modlili się do cudami słynącego zakonnika rodem z Kamienia Śląskiego. Mimo wielokrotnych prób zniszczenia świątyni przez najeźdźców, ta ocalała, a wraz z nią wszyscy w niej zgromadzeni ${ }^{9}$. Zgodnie z przekazem św. Jacek, pojawiający się wówczas nad kościołem, innowierców chcących zburzyć dom Boży „postrącał z muru i oślepił" [Kolberg, 1871, 49].

Wśród licznych legend o zakonniku z pewnością do jednej z najbardziej znanych należy ta o cudownym podniesieniu przez niego zniszczonych gradem zasiewów we wsi Kościelec koło Proszowa [Woroniecki, 2007, 178]. O wydarzeniu tym wspomina także Oskar Kolberg w piątym tomie Ludu: „Synowiec biskupa Iwona Odrowąża, święty Jacek, który przywdział habit dominikański r. 1257, a ciało jego spoczywa w kościele św. Trójcy, słynie cudem, że wskutek modlitwy jego na polu wsi Kościelniki, zbite gradem kłosy, leżące na ziemi pokotem, wstały razem, wyprostowały się i strzeliły jak dawniej ku niebu, bujnem ziarnem" [Kolberg, 1871, 14]. Współcześnie nawiązując do wspomnianej legendy - w kościołach dominikańskich w dniu odpustu ku czci św. Jacka święci się kłosy zbóż, które następnie zabierane są przez wiernych do domów:

Panie, Ojcze Święty, Wszechmogący wieczny Boże, który za przyczyną św. Jacka, Twojego Wyznawcy, w przedziwny sposób podniosłeś kiedyś ze zniszczenia zbite gradem łany zbóż, racz podnieść dzisiaj serca Twoich wiernych z upadku grzechu i zwróć je ku pragnieniu rzeczy nieprzemijających, a te pszenne kłosy przyniesione ku czci św. Jacka racz boską swoją mocą pobłogosławić i taką przez Twoje niebieskie błogosławieństwo daj im moc, by do domu, gdzie z wiarą przechowywać się je będzie, nie wtargnął nigdy niedostatek ani głód, lecz za wstawiennictwem tegoż św. Jacka niech obfituje w nich błogosławieństwo niebios i doczesna pomyślność. Spraw także, by żadna nawałnica nie była w stanie zniszczyć plonów ziemi, a wierny Ci lud, wolny od wszelkich zagrożeń i niepokoju, mógł Ci służyć z miłością przez Chrystusa Pana Naszego amen ${ }^{10}$.

\footnotetext{
${ }^{9}$ Dostęp: 3.02.2020, http://powiat.oswiecim.pl/index.php/strony/10150/news/1798.

${ }^{10}$ Dostęp: 2.02.2020, https://gidle.dominikanie.pl/2018/08/21/odpust-sw-jacka-nagrania/.
} 
W tradycyjnej kulturze ludowej dzień św. Jacka na Podhalu i Spiszu był również świętem pasterskim. Na halach pasterze modlili się do świętego o szczęśliwy wypas, a ziołami poświęconymi w uroczystość Matki Boskiej Zielnej okadzali zagrodę z owocami i szałasy ${ }^{11}$.

\section{4. ŚW. JACEK W PRZYSŁOWIACH I KULINARIACH}

Bohaterami licznych paremii są święci. Ich obecność w przysłowiach wynika między innymi z innego dawniej sposobu oznaczania dni tygodnia, a mianowicie według kalendarza religijnego. Na co dzień posługiwano się nie datami, lecz nazwami świąt kościelnych, i w ten sposób święci kojarzeni byli z porami roku („Od św. Marcina zima się zaczyna”), zjawiskami atmosferycznymi („Na św. Kazimierza dzień się z nocą przymierza”), z pracami gospodarskimi („Św. Jan trawę kosi”), z początkiem okresów religijnych („Św. Katarzyna adwent rozpoczyna, św. Jędrzej jeszcze mędrzej”), ze zjawiskami społecznymi („Na św. Idzi w swaty do mnie przyjdzi”), z dniami targowymi w poszczególnych miejscowościach („Na święty Jacek w Warszawie jarmacek”), wreszcie z licznymi prognostykami pogody („Gdy deszcz w św. Michała, będzie łagodna zima cała”) i urodzaju („W dzień św. Marka sieje się tatarka") [Tomicki, 1981, 44].

Przysłów o św. Jacku w polskich zbiorach paremiograficznych jest kilkanaście. Są wśród nich zarówno prognostyki pogodowe: „Jeżeli w dzień św. Jacka deszcz nie pada, będzie jesień sucha”, „Gdy na Jacka pogodnie, suche w jesieni dnie”, jak i przywołujące różne profesje: „Szwaczka od św. Jacka”. Najliczniejszą grupę tworzą te z komponentem kulinarnym w postaci placka lub pierogów: „Na święty Jacek z nowej pszenicy placek”, „Na święty Jacek będzie nowy placek”, „Na świętego Jacka najecie się placka”, „Na świętego Jacka trza upiec placka”, „Na świętego Jacka ukoś owsa i upiec placka”, „Ze wszystkich świętych najlepszy Jacek, bo kto żyje dostał placek”, „Święty Jacek zjadł z flakami placek”, „O święty Jacku z pierogami”, „Święty Jacku z pierogami, módl się za nami”, „Wygląda, jak święty Jacek z pierogami” [Adalberg, 1889-1894, 178].

Przywołane kulinaria nie są przypadkowe. Placek, pieróg (piróg) przyrządzany w połowie sierpnia, „na świętego Jacka”, miał być ze zboża z pierwszego przemiału, a więc z plonów dopiero co zebranych z pola; stąd po

\footnotetext{
${ }^{11}$ Dostęp: 15.02.2020, https://cbr.gov.pl/index.php/kultura-w-sieci/polski-rokobrzedowy/item/9 98-swieci-patroni-w-zyciu-mieszkancow-wsi-polskiej-obchody-sierpniowe.html.
} 
przednówkowym głodzie „przychodzi św. Jacek z pierogami”. Pierogi zgodnie z przekazami ludowymi - są nawiązaniem do dawnych czasów, kiedy w czasie głodu w Krakowie po najeździe tatarskim w 1241 r. sam św. Jacek miał je wyrabiać i karmić nimi mieszkańców. Dzięki świętemu potrawa ta, przywieziona przez niego z Rusi, stała się popularna na ziemiach polskich. Jest również odwołanie do cudu, jakiego dokonał zakonnik w Kościelcu, unosząc zniszczone gradem kłosy zbóż. Z mąki tych właśnie ziaren - w wersji dopowiedzianej później - przygotowano pierogi, którymi ugoszczono św. Jacka [Rożek, 2012, 172-178]. Od kilkunastu lat w Krakowie odbywa się festiwal pierogów, podczas którego zwycięzca najsmaczniejszych otrzymuje statuetkę z wizerunkiem św. Jacka z pierogami. Oprócz dawnej stolicy Polski, także inne miejscowości przywołują osobę świętego i charakterystyczną potrawę, którą częstowano dominikanina podczas jego pobytu (np. w Będziemyślu), albo on sam ją przygotował (wieś Nockowa).

Współcześnie w dobie odwoływania się do dziedzictwa kulturowego i potencjału, jakie ono niesie $\mathrm{w}$ różnych aspektach życia społecznego, gospodarczego, politycznego, także biografie świętych coraz częściej wykorzystywane są w rozmaitych działaniach promocyjnych. Wydaje się, że w ostatnim czasie to właśnie kulinaria kojarzone z konkretnymi osobami świętych stały się nierzadkim motywem przewodnim takich praktyk [Świtała-Trybek, 2016, 147-166]. Przykładem są np. pieczone pierogi św. Jacka ze wsi Nockowa, które w kategorii gotowe dania i potrawy $\mathrm{z}$ województwa podkarpackiego zostały wpisane na Listę Produktów Tradycyjnych w 2010 r. Z powstaniem tej potrawy związana jest także legenda ${ }^{12}$.

${ }^{12}$ „Jacek Odrowąż, idąc na misje na Ruś Kijowską, zatrzymał się we wsi Nockowej, aby podkuć konia. Jadąc dalej napotkał bagna, na których jego koń stracił życie. Głodny i spragniony postanowił zawrócić do wsi, gdy wnet zobaczył na wzgórzu idących żeńców. Poprosił o wodę i jedzenie. Żeńcy napoili św. Jacka, jednak nie mieli nic do jedzenia. Ten poprosił, aby zabrali do domu snop pszenicy, wykruszyli ziarna i w żarnach zmielili. Żeńcy tak zrobili, ale mąki było mało, wtedy św. Jacek zobaczył odcedzający się twaróg i kazał dołożyć do mąki i zagnieść ciasto. Następnie kazał im przynieść z pola liście kapusty ugotować i posiekać, ale farszu wciąż było mało. Wtedy poprosił ich, aby nazbierali białej simby, czyli pieczarek, które w tym czasie rosły na dziko na ugorach. Nieufni żeńcy uważali, że pieczarki są grzybami trującymi i nie zgodzili się. Wtedy św. Jacek wziął pieczarkę, ułamał i zjadł surową. Widząc to żeńcy nazbierali pieczarek, podgotowali i posiekali, a na końcu dodali do farszu. Ulepili pierogi i połowę ugotowano, a połowę upieczono i ułożono w misce św. Jacka. Na ucztę zostali zaproszeni wszyscy mieszkańcy wsi. Uważano to za cud, a miska po tych pierogach znajduje się do dnia dzisiejszego w Będziemyślu. Pierogi te jadano bardzo często i były one swego rodzaju rarytasem. Podczas spożywania pieczonych pierogów odmawiano modlitwę: «Św. Jacku z pierogami, módl się do Boga za nami, żeby te pierogi cały rok na stole były i nas od głodu broniły»”. Źródło: dostęp: 12.02.2020, http://www. 
Jeszcze inną formą popularyzacji pierogów jest ich serwowanie podczas festynów, jarmarków odbywających się w różnych miejscowościach naszego kraju, także podczas odpustów parafialnych ku czci św. Jacka, np. w Kamieniu Śląskim, Stepnicy, Leszczynach. W tej ostatniej dodatkowo organizuje się konkurs kulinarny na najlepsze „Jackowe pierogi”.

W Kamieniu Śląskim, miejscu urodzenia dominikanina, gospodynie wypiekają również ciastka nazywane rogalikami św. Jacka, które są coraz bardziej popularne w innych częściach Śląska Opolskiego, stając się rozpoznawalnym produktem kulinarnym tego regionu [Bedrunka red., 2016, 20]. $\mathrm{W}$ jednej z restauracji w tejże miejscowości można posmakować także innego specjału - golonki św. Jacka. Z pewnością potrawa ta nie ma nic wspólnego ze świętym, co zaznaczono już w przewodniku kulinarnym: „Wprawdzie wydaje się, że ze znanych potraw św. Jacek promował tylko swoje słynne pierogi, możemy jednak przypuszczać, co by powiedział na taki przysmak: chrupiący, pachnący... Bez dwóch zdań - ta golonka nawet świętego by skusiła" [Tomczyk-Miczka, Mielec, 2015, 76]. W przypadku obu wyróżnionych specjałów przywołanie w nazwie potrawy osoby św. Jacka ma na celu przede wszystkim zwrócenie uwagi na jego postać w kontekście miejscowości, z której on pochodzi. Oczywiście, jest to forma reklamy samego produktu.

Jak zatem widać, kulturowa rola św. Jacka współcześnie została wzbogacona (albo przypomniana) o treści odnoszące się do zwykłej ludzkiej egzystencji - jedzenia. Określone kulinaria, dzięki odpowiednim działaniom, często instytucjonalnym, także środkom społecznego komunikowania i przekazom międzypokoleniowym (przysłowia) kojarzone są z jego osobą. Święty - jak chce tradycja - w niektórych przypadkach miał osobisty udział w ich przygotowaniu bądź spożyciu. Nie jest to zjawisko całkowicie nowe, bo od pokoleń w kulturze polskiej i europejskiej znani są święci, którym przypisane są wybrane pokarmy, np. św. Marcinowi - gęś, św. Jerzemu - piróg (podłużny chleb), św. Agacie - sól i chleb, św. Dorocie - jabłka [Świtała-Trybek, 2009, 135-150].

W polskiej tradycji i kulturze religijnej św. Jacek od wieków darzony jest kultem, o czym świadczą zarówno powstałe przed wiekami kościoły i kaplice, jak również nowo budowane świątynie, którym patronuje. Cześć mu oddawana najsilniejsza jest w miejscowościach, w których żył i prowadził

minrol.gov.pl/Jakosc-zywnosci/Produkty-regionalne-i-tradycyjne/Lista-produktow-tradycyjnych /woj.-podkarpackie/Pieczone-pierogi-sw.-Jacka. 
działalność kaznodziejską oraz tam, gdzie znajdują się klasztory dominikańskie. Jedyne sanktuarium w Polsce poświęcone św. Jackowi znajduje się w Kamieniu Śląskim, miejscu jego urodzenia. Zostało ono ustanowione w $1994 \mathrm{r}$. (jego pełna nazwa brzmi Sanktuarium św. Jacka Centrum Kultury i Nauki Wydziału Teologicznego Uniwersytetu Opolskiego) i jest ważnym ośrodkiem pielgrzymkowym, rekolekcyjnym, miejscem spotkań ekumenicznych, odbywają się tu różne konferencje oraz sympozja naukowe o charakterze krajowym i międzynarodowym.

W tradycji ludowej św. Jacek obecny jest w licznych legendach, podaniach i przysłowiach, zwłaszcza tych przywołujących określone kulinaria. Współcześnie, w dobie odwoływania się do dziedzictwa kulturowego materialnego i niematerialnego, postać dominikanina cieszy się popularnością dzięki bardzo lubianej i chętnie spożywanej przez Polaków potrawie. Nie dziwi zatem fakt, że „święty od pierogów” czy „święty z pierogami” to najczęściej pojawiające się skojarzenia w środkach masowego przekazu na temat św. Jacka. Legendy o nim stanowią też dzisiaj materiał promocyjny, chętnie wykorzystywany w turystyce kulturowej, pojawiają się w rozmaitych wydawnictwach (przewodnikach, folderach), docierając tym samym do szerokiego grona osób.

\section{BIBLIOGRAFIA}

ADALBERG, Samuel, oprac. Księga przystów, przypowieści i wyrażeń przysłowiowych polskich. Warszawa 1889-1894.

Borkowski, Zbigniew. Święty Jacek. Częstochowa: Edycja Świętego Pawła, 2019.

CAMILlERI, Rino. Wielka księga świętych patronów. Kielce: Jedność, 2002.

DrabinA, Jan. „Wokół tragicznego zdarzenia z roku 1367 w Bytomiu”. W Szkice z dziejów Bytomia, red. Jan Drabina, 107-120. Bytom: Towarzystwo Miłośników Bytomia, 1984.

FuSCO, Roberto. „Jackowe modele ikonograficzne we włoskich obrazach ołtarzowych w okresie późnego manieryzmu i wczesnego baroku”. W Święty Jacek Odrowąż Apostot Pótnocnej Europy, red. ks. A. Nocoń, ks. A. Wuwera, 62-92. Roma-Katowice: Księgarnia św. Jacka, 2012.

JACEK Z WygieŁzowa. Wojsko św. Jadwigi. Bytom, 1922.

KANIOR, Marian OSB. „Święty Jacek”. W Polscy święci 8, red. Joachim Roman Bar OFMConv, 84-122. Warszawa: Akademia Teologii Katolickiej, 1987.

Kolberg, Oskar. Lud. Jego zwyczaje, sposób życia, mowa, podania, przystowia, obrzędy, gusła, zabawy, pieśni, muzyka i tańce. Krakowskie, część pierwsza. Kraków, 1871.

Ku czi św. Jacka. Opole (Oppeln O.-S.): Wydał Związek Polskich Kół Śpiewaczych na Śląsku Opolskim, 1938.

LoMPA, Józef. Bajka i podania, Wrocław, 1965.

Opolskie smaki 5, red. Karina Bedrunka i in. Opole, 2016. 
RożEK, Michał. Magia kultury. Kraków: Wydawnictwo Petrus, 2012.

SKARGA, Piotr, ks. Żywoty świętych polskich. Kraków: WAM, 2011.

SPIEŻ, Jan Andrzej OP. Św. Jacek Odrowąż. Kraków: WAM, 2007.

SzCZECH, Bernard. Srebrne miasto czyli bytomskie legedny i podania. Bytom: Platan, 2000.

ŚwitaŁa-Trybek, Dorota. „Na świętego Marcina najlepsza gęsina. Święci i kulinaria”. W: Święci $i$ świętość w literaturze i kulturze, red. Maria Kopsztejn i Barbara Szargot, 135-150. Bytom: Akademia Humanistyczno-Ekonomiczna w Łodzi, 2009.

ŚwitAŁA-TRYBeK, Dorota. „Sałatki mnicha, pierogi św. Jacka, kiełbaski z refektarza... Na szlaku świętych smaków"'. Zeszyty Naukowe. Turystyka i Rekreacja nr 1 (2016): 147-166.

Tomczyk-Miczka, Elżbieta, Mielec, Piotr. Opolski Bifyj. Przyjazny przewodnik kulinarny. Kraków: Opolska Regionalna Organizacja Turystyczna, 2015.

WALCZAK, Marek. „Obraz Wizja św. Jacka Odrowążu jako vera effigies pierwszego polskiego dominikanina". W Sztuka w kręgu krakowskich dominikanów, red. Anna Markiewicz, Marcin Szyma, Marek Walczak, 595-623. Kraków: Esprit, 2013.

WiLENIEC-SøndERBY, Bożena Anna. „Św. Jacek w Skandynawii: misja czy fikcja?”. W Święty Jacek Odrowąż Apostol Pólnocnej Europy, red. ks. A. Nocoń, ks. A. Wuwera, 110-124. Roma-Katowice: Księgarnia św. Jacka, 2012.

WoronIECKI, Jacek OP. Święty Jacek Odroważ i sprowadzenie Zakonu Kaznodziejskiego do Polski. Kraków-Katowice: Esprit, 2007.

ZALEWSKI, Wincenty SDB. Święci na każdy dzień. Warszawa: Wydawnictwo Salezjańskie, 1989.

\section{STRONY INTERNETOWE}

Dostęp: 1.02.2020. https://silesia.edu.pl/index.php?title=\%C5\%9Aw._Jacek.

Dostęp: 1.02.2020. http://www.miesiecznik.wdrodze.pl/index_special.php?mod=archiwumtekst\& id $=15950 \# . X k C W K T F K j I U$.

Dostęp: 2.02.2020. https://gidle.dominikanie.pl/2018/08/21/odpust-sw-jacka-nagrania/.

Dostęp: 15.02.2020. https://cbr.gov.pl/index.php/kultura-w-sieci/polski-rok-obrzedowy/item/998swieci-patroni-w-zyciu-mieszkancow-wsi-polskiej-obchody-sierpniowe.html.

Dostęp: 12.02.2020. http://www.minrol.gov.pl/Jakosc-zywnosci/Produkty-regionalne-i-tradycyjne/Lista-produktow-tradycyjnych/woj.-podkarpackie/Pieczone-pierogi-sw.-Jacka.

\section{ŚWIĘTY JACEK W RELIGIJNOŚCI LUDOWEJ I W KULTURZE POLSKIEJ}

\section{Streszczenie}

Święty Jacek Odrowąż, dominikanin urodzony w Kamieniu Śląskim nieopodal Opola, kanonizowany w 1594 r. przez papieża Klemensa VIII, należy do najwybitniejszych postaci XIII wieku. Jest uważany za twórcę polskiej prowincji dominikanów za inicjatora powstania wielu klasztorów w Polsce, Prusach, Czechach (Znojnie, Igławie, Ołomuńcu, Pradze) i Austrii (we Friesach na pograniczu Styrii i Karyntii). Nazywany Apostołem Północnej Europy, Apostołem Słowian, Światłem Północy, Lux ex Silesiae (Światłem ze Śląska), prowadził misje ewangeli- 
zacyjne wśród ludów zamieszkujących dzisiejsze państwa bałtyckie oraz stepy nadczarnomorskie, także w Rusi Kijowskiej.

Przedmiotem niniejszego artykułu jest próba omówienia i analizy kultu św. Jacka w polskiej tradycji i kulturze religijnej. Autorka przedstawia biografię świętego, legendy i podania z nim związane, także przysłowia, zwyczaje agrarne i kulinaria. Materiały, które stały się podstawą omówienia, pochodzą z badań terenowych, które autorka prowadziła w latach 2015-2020, jak i z dostępnej literatury przedmiotu.

Słowa kluczowe: św. Jacek Odrowąż; kult; religijność; legendy; pierogi. 